\title{
СУДЕБНАЯ ЗАЩИТА: ПОНЯТИЕ, ЗНАЧЕНИЕ, МЕСТО В СИСТЕМЕ ЗАЩИТЫ ПРАВ И СВОБОД ЧЕЛОВЕКА И ГРАЖДАНИНА
}

\begin{abstract}
Аннотация: В течение двадцати лет с момента принятия Конституции Российской Федерации российское государство и общество находятся в постоянном развитии. Актуальным является вопрос эффективности защиты прав и свобод человека и гражданина. В настоящей статье рассматриваются такие категории как «правовая защита», «государственная защчта», «судебная защчита» прав и свобод человека и гражданина, определяется их соотношение. Автор, используя сравнительно-правовой метод исследования, пришел к выводу, что правовая защита является категорией, первичной по отношению к государственной и судебной зашчте. Особое внимание уделяется судебной зашите, определяются присущие ейхарактерные черты. Судебная зашчита рассматривается в двух аспектах: с точки зрения субъектов, обращующихся в суд за защитой и с точки зрения судебньх органов, реализуюших свои полномочия при отправлении правосудия. Результатом изучения данной категории с указанных позиций являются выработанные автором с использованием формально-юридического метода исследования определения понятия «судебная защита прав и свобод человека и гражданина». Кроме того, в статье затрагиваются проблемы эффективности функиионирования судов и предлагаются варианты их решения, дается оценка политике государства, направленной на реформирование судебной системы. Результаты исследования могут быть использованы в дальнейшем при изучении проблем судебной зашиты конституционных прав и свобод человека и гражданина в Российской Федерации.
\end{abstract}

Abstract: In the twenty years since the adoption of the Constitution of the Russian Federation, the Russian state and its society have continued to develop. The effectiveness of the protection of the rights and liberties of the man and the citizen is a current issue. This article examines terms such as 'legal protection', 'state protection', and 'judicial protection' as they apply to the rights and liberties of the man and the citizen, and considers their correlation. Comparative legal research results in the conclusion that legal protection is a category most closely related to state and judicial protection. Particular attention is given to judicial protection, and its inherent characteristics are outlined. Judicial protection is considered in two ways: from the perspective of parties applying to the courts for protection, and from the perspective of the judiciary exercising their powers in the administration of justice. As a result of this analysis, and by using the formal legal research method, the author presents a definition for the idea of 'judicial protection of the rights and freedoms of the man and the citizen.' The article also addresses obstacles to the effective functioning of the courts and offers some solutions, as well as assessing government policy to reform the judicial system. This article can be used in the study of problems of judicial protection of constitutional rights and liberties of man and citizen in the Russian Federation.

Ключевье слова: Конституция Российской Федеращии, гражданское общество, права человека, правовая защита, государственная защита, судебная защита, правосудие, судебные органь, объединение судов, эффективность правосудия Keywords: Constitution of the Russian Federation, civil society, human rights, protection of rights, state protection, judicial protection, administration of justice, judicial bodies, court amalgamation, effectiveness of the administration of justice

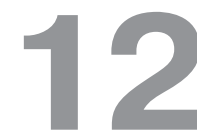

декабря 2013 г. исполняется ровно двадцать лет со дня принятия Конституции Российской Федерации ${ }^{1}$. Эта дата является очень знаменательной для российского общества. Сам факт принятия Конституции РФ на всенародном голосовании свидетельствует о нача-

\footnotetext{
${ }^{1}$ Конституция Российской Федерации (принята всенародным голосованием 12.12.1993) (с учетом поправок, внесенных Законами РФ о поправках к Конституции РФ от 30.12.2008 N 6-ФКЗ, от 30.12.2008 N 7-ФКЗ) // Справочно-правовая система «Консультант Плюс».
}

ле новой эпохи развития государства, зарождении гражданского общества. Несомненно, данное событие позитивно отразилось на жизни российского народа, ведь гражданское общество строится на признании свободы и инициативы человека и объединений людей как в политической, так и в экономической областях ${ }^{2}$. Гражданское общество можно охарактеризовать и как «состояние обще${ }^{2}$ См.: Баглай М.В. Конституционное право Российской Федерации.
М.: НОРМА, 2007. С. 18. 


\section{Право и политика 11 (166) • 2013}

ства, когда человек признается высшей ценностью, соблюдаются и защищаются его права и свободы, когда под контролем общества и его организаций находится государственная и общественная жизнь, основывающаяся на правовых ценностях, идеалах демократии и справедливости» ${ }^{3}$.

Именно Конституция РФ является основным законом страны, в котором закреплены основные права и свободы человека и гражданина, гарантируемые государством. Это обеспечивается, в том числе, путем разделения властей на законодательную, исполнительную и судебную. Основатель теории разделения властей - Ш. Монтескье, в своем труде «О духе законов» говорил, что «есть три рода власти: власть законодательная, власть исполнительная, ведающая вопросами международного права, и власть исполнительная, ведающая вопросами права гражданского. В силу первой части государь или учреждение создает законы, временные или постоянные, и исправляет или отменяет существующие законы. В силу второй он объявляет войну или заключает мир, посылает и принимает послов, обеспечивает безопасность, предотвращает нашествия. В силу третьей власти он карает преступления и разрешает столкновения частных лиц. Последнюю власть можно назвать судебной, а вторую - просто исполнительной властью государства» ${ }^{4}$. В своем модернизированном виде эта концепция реализована в России: каждая ветвь власти представлена системой государственных органов, выполняющих свои задачи и обеспечивающих конституционный строй страны.

Нельзя отрицать тот факт, что между субъектами общественных отношений нередко возникают конфликты и социальные противоречия, имеют место нарушения прав и свобод человека и гражданина. Конституционный Суд Российской Федерации в своем постановлении от 2 февраля 1996 г. № 4-П указал, что государство обязано признавать, соблюдать и защищать права и свободы, создавая при этом эффективные правовые механизмы устранения любых нарушений, допущенных его органами и должностными лицами ${ }^{5}$ Естественно, что созда-

\footnotetext{
${ }^{3}$ Власенко Н.A. Теория государства и права: Учебное пособие. 2-е изд., перераб., доп. и испр. М.: Издательство «Проспект», 2011. C. 112.

${ }^{4}$ Монтескье Ш. Избранные произведения. М.: Госполит-издат, 1955. C. 155.

${ }^{5}$ См.: Постановление Конституционного Суда РФ от 02.02.1996 N 4-П «По делу о проверке конституционности пункта 5 части второй статьи 371 , части третьей статьи 374 и пункта 4 части
}

ние обозначенных механизмов должно быть легитимным. Иными словами, защита прав и свобод человека и гражданина должна обеспечиваться правовыми средствами: как путем формального закрепления общеобязательных правил поведения (правовых норм), так и их надлежащим применением всеми субъектами правоотношений, в том числе и государственными органами.

Известно, что право выполняет две основные функции: регулятивную и охранительную. Последняя характеризуется такими категориями, как «охрана прав» и «защита прав» ${ }^{6}$. В связи с этим в науке нет единого подхода к соотношению данных двух понятий. Так, Н.С. Малеин считает, что категория «охрана прав» является более обширной и включает в себя все юридические правила по поводу определенного блага. В свою очередь, под защитой права он понимает меры, принимаемые государством в случаях, когда право нарушено ${ }^{7}$. Согласимся с мнением С.С. Алексеева, который рассматривает защиту прав как принудительную деятельность государства, основной задачей которой является восстановление нарушенного права и обеспечение юридической обязанности. По его мнению, защита прав происходит в рамках особых охранительных правоотношений ${ }^{8}$. Таким образом, в современной правовой действительности целесообразно говорить о тождественности понятий «охрана прав» и «защита прав».

В России правовая защита человека и гражданина гарантируется Конституцией. В частности, в статьях 45 и 46 Конституции РФ закреплены гарантии государственной и судебной защиты прав и свобод человека и гражданина, возможность защищать свои права и свободы всеми способами, не запрещенными законом.

В течение последних двадцати лет происходит непрерывное развитие институтов гражданского общества, под которыми понимаются «организованные так или иначе объединения граждан, действия которых направлены на реализацию каких-либо целей и задач, на разрешение собственных, общих

второй статьи 384 Уголовно-процессуального кодекса РСФСР в связи с жалобами граждан К.М. Кульнева, В.С. Лалуева, Ю.В. Лукашова и И.П. Серебренникова»

${ }^{6}$ См.: Смирнов А.П. Соотношение понятий «охрана прав» и «защита прав» // Вестник Томского государственного университета. 2010. № 331. C. 123 - 125

${ }^{7}$ См.: Малеин Н.С. Охрана прав личности советским законодательством. М., 1985. С. 18-19

${ }^{8}$ См.: Алексеев С.С. Общая теория права. М., 1981. Т. 1. С. 280 
для групп проблем»9. Таким образом, функционирование институтов гражданского общества есть непосредственная реализация гражданами правовой защиты.

Правовую защиту можно считать более общим понятием по сравнению с государственной или судебной защитой прав и свобод человека и гражданина: наряду с двумя последними категориями в нее входит самостоятельная защита гражданами своих прав и свобод. Однако представляется, что в большинстве случаев права и свободы человека и гражданина обеспечиваются и защищаются путем государственного принуждения, за счет которого и обеспечивается высокая эффективность защиты. Особенно необходима государственная защита в тех случаях, когда право лица уже нарушено.

Государственную защиту прав и свобод человека и гражданина следует определить как принудительную деятельность государства, направленную на восстановление нарушенного права и обеспечение юридической обязанности, осуществляемую государственными органами в особом процессуальном порядке.

Проанализировав положения Конституции Российской Федерации и принятых в соответствии с ней федеральных законов, можно выделить административный и судебный порядок защиты прав и свобод человека и гражданина.

В основе административного порядка лежит право граждан на обращение в государственные органы и органы местного самоуправления, предусмотренное ст. 33 Конституции РФ.

В зависимости от компетенции конкретного органа, рассматривающего обращение, конституционные права граждан защищаются по-разному.

Так, прокурор при рассмотрении обращения гражданина обязан дать мотивированный ответ. Если в ходе проверки выявляются лица, совершившие правонарушения, выносится соответствующий акт прокурорского реагирования, принимаются меры по привлечению к установленной законом ответственности виновных лиц ${ }^{10}$. Органы исполнительной власти могут дать обратившемуся гражда-

\footnotetext{
${ }^{9}$ Халий И.А. Институты гражданского общества в современной России. К методологии изучения // Россия реформирующаяся. Ежегодник / Отв. Ред. М.К. Горшков. - Вып.6. - М.: Институт социологии РAH, 2007. URL: http://www.civisbook.ru/files/File/ Khaliyy.pdf (дата обращения: 24.10.2013).

${ }^{10}$ См.: Федеральный закон от 17.01.1992 N 2202-1 (ред. от 07.05.2013) «О прокуратуре Российской Федерации» // Справочноправовая система «Консультант Плюс».
}

нину разъяснения по конкретному вопросу, а также принять иные меры, направленные на защиту прав в пределах своих полномочий.

Судебная защита является одним из элементов государственной защиты прав и свобод человека и гражданина. Считаем правильной точку зрения О.Я. Белявской, согласно которой «судебная защита - это один из способов государственной защиты прав и свобод человека и гражданина. Она является самостоятельным направлением государственной деятельности, осуществляемым специальными органами - судами» ${ }^{11}$.

Ю. О. Столярова отмечает, что институт судебной защиты является значимым элементом современной системы конституционных гарантий реализации прав и свобод человека и гражданина ${ }^{12}$. Об этом свидетельствует и статистика. По данным Судебного департамента при Верховном суде Российской Федерации за 2012 год судами общей юрисдикции и мировыми судьями по первой инстанции рассмотрено 947647 уголовных дел, 10306700 гражданских дел ${ }^{13}$. Кроме того, в Конституционный Суд Российской Федерации за указанный период поступило 18745 обращений ${ }^{14}$.

Можно согласиться и с мнением В.Б. Вершинина, который утверждает, что судебная защита, будучи разновидностью как государственной, так и правовой защиты, является наиболее эффективным из всех выработанных мировой практикой способом охраны прав и законных интересов субъектов социальных связей. Уровень судебной защиты - важнейший показатель правового характера государства и демократичности общества ${ }^{15}$.

\footnotetext{
${ }^{11}$ Белявская О.Я. Конституционное право человека и гражданина на судебную защиту: понятие, проблемы реализации: дис...канд. юрид.наук, СПб., 2007. С. 17.

${ }^{12}$ См.: Столярова Ю. О. Судебная защита прав граждан как комплексный политико-правовой институт // Известия Российского государственного педагогического университета им. А.И. Герцена. 2008. № 69. URL: http://cyberleninka.ru/article/n/sudebnaya-zaschitaprav-grazhdan-kak-kompleksnyy-politiko-pravovoy-institut (дата обращения: 24.10.2013).

${ }^{13}$ См.: Сводные статистические сведения о деятельности федеральных судов общей юрисдикции и мировых судей за 2012 год. URL: http://www.cdep.ru/index.php?id=79\&item=1775 (дата обращения: 20.10.2013).

${ }^{14}$ См.: Обращения, поступившие в Конституционный Суд Российской Федерации в 1995-2012 гг. URL: http://www.ksrf.ru/ru/ Treatments/Pages/NewReference.aspx (дата обращения: 20.10.2013).

${ }^{15}$ См.: Вершинин В.Б. Судебная защита как комплексный институт российского права: Автореф. дис...канд.юрид.наук, Саратов. 2011. C. 3.
} 


\section{Право и политика 11 (166) • 2013}

В Российской Федерации действуют федеральные суды, конституционные (уставные) суды и мировые судьи субъектов Российской Федерации, составляющие судебную систему Российской Федерации ${ }^{16}$ и призванные осуществлять судебную защиту прав и свобод человека и гражданина.

В юридической литературе отсутствует универсальное определение понятия «судебная защита прав и свобод человека и гражданина». По нашему мнению, разработка такого определения могла бы способствовать систематизации научных знаний о данной категории. Также такое определение может быть полезным при дальнейшем изучении конституционно-правового содержания общественных отношений, возникающих по поводу нарушения прав и свобод человека и гражданина.

Представляется, что судебную защиту прав и свобод человека и гражданина необходимо рассматривать в двух аспектах: с точки зрения заинтересованных субъектов, обращающихся в суд за защитой и с точки зрения судебных органов, реализующих свои полномочия при отправлении правосудия.

Рассматривая данную категорию, выделим некоторые присущие ей черты.

Во-первых, судебная защита инициируется заинтересованными субъектами с целью защиты прав и свобод: любой деликт, будь он гражданско-, административно-, или уголовно-правовым, всегда является проявлением конфликта субъектов соответствующих правоотношений. При этом лицо, чье право нарушено, обладает заинтересованностью в его восстановлении. Если инициатором судебного разбирательства является государственный орган, то речь может идти о защите прав неопределенного круга лиц, а так же о реализации государственных полномочий в сфере охраны правопорядка.

Во-вторых, заинтересованными субъектами могут являться как физические, так и юридические лица и индивидуальные предприниматели.

В обоснование нашей позиции приведем следующий пример. В соответствии с ч. 1 ст. 30 Конституции РФ каждый имеет право на объединение, включая право создавать профессиональные союзы для защиты своих интересов. Свобода деятельности общественных объединений гарантируется.

Профессиональный союз является юридическим лицом, создаваемым в форме общественных объ-

\footnotetext{
${ }^{16}$ Федеральный конституционный закон от 31.12.1996 N 1-ФКЗ (ред. от 25.12.2012) «О судебной системе Российской Федерации» // Справочно-правовая система «Консультант Плюс».
}

единений ${ }^{17}$. Это означает, что данные организации обладают правосубъектностью, что позволяет им обращаться в судебные органы в соответствии с компетенцией, установленной ст. 23 Федерального закона от 12.01.1996 N 10-Ф3 «О профессиональных союзах, их правах и гарантиях деятельности».

Таким образом, профсоюзная организация, реализуя конституционное право на обращение в суд и выступая в суде, осуществляет судебную защиту трудовых прав работников. Это позволяет сделать вывод о том, что судебная защита прав и свобод человека и гражданина может быть реализована не только физическими, но и юридическими лицами.

Аналогичным образом можно подвергнуть анализу нормы законодательства о коммерческих юридических лицах. Ст. 34 Конституции Российской Федерации закрепляет право каждого на использование своих способностей и имущества для осуществления предпринимательской деятельности. В силу норм гражданского законодательства о юридических лицах, учредители и участники имеют вещные права на имущество юридического лица. Таким образом, внесение имущества в уставный или складочный капитал юридического лица можно рассматривать как способ реализации конституционного права на осуществление предпринимательской деятельности, предусмотренное ст. 34 Конституции Российской Федерации. Более того, учредители и участники коммерческих организаций осуществляют комплекс корпоративных прав. В частности, ч. 1 ст. 28 Федерального закона от 08.02.1998 N 14-Ф3 «Об обществах с ограниченной ответственностью» предусмотрено, что общество вправе ежеквартально, раз в полгода или раз в год принимать решение о распределении своей чистой прибыли между участниками общества ${ }^{18}$. Какое-либо нарушение имущественных прав юридического лица непосредственно отражается на размере полученной им прибыли, а значит, и на доходах его участников. Иными словами, обращение юридического лица в арбитражный суд в связи с возникновением спора, вытекающего из экономических отношений, в какой-то степе-

\footnotetext{
${ }_{17}$ См.: Федеральный закон от 12.01.1996 N 10-Ф3 (ред. от 28.12.2010) «О профессиональных союзах, их правах и гарантиях деятельности», Федеральный закон от 19.05.1995 N 82-Ф3 (ред. от 20.07.2012) «Об общественных объединениях» // Справочноправовая система «Консультант Плюс».

18 Федеральный закон от 08.02.1998 N 14-ФЗ(ред. от 29.12.2012) «Об обществах с ограниченной ответственностью» // Справочноправовая система «Консультант Плюс».
} 
ни коррелирует с защитой имущественных прав участников хозяйствующего субъекта. Безусловно, взаимозависимость этих двух процессов не лежит на поверхности, однако не вызывает сомнения тот факт, что благосостояние участников напрямую зависит от благосостояния юридического лица.

Таким образом, в широком смысле субъектом судебной защиты прав и свобод человека и гражданина может являться и юридическое лицо, если рассматривать последнее как объединение граждан в своих интересах с целью осуществления определенной не запрещенной законом деятельности. В данном случае защите подлежит конституционное право на осуществление предпринимательской деятельности, а так же иные имущественные права субъектов такой деятельности. С учетом такой специфики, защита прав и свобод субъектов предпринимательской деятельности должна осуществляться в арбитражном суде.

В-третьих, судебная защита предполагает реализацию заинтересованными субъектами своих процессуальных прав.

Судебная защита прав и свобод человека и гражданина может осуществляться только в форме реализации процессуальных прав, предусмотренных законом. Об этом свидетельствует ст. 1 Уголовнопроцессуального кодекса Российской Федерации ${ }^{19}$, в соответствии с которой порядок уголовного судопроизводства на территории Российской Федерации устанавливается настоящим Кодексом, основанным на Конституции Российской Федерации. В гражданском судопроизводстве есть аналогичная норма: порядок гражданского судопроизводства в федеральных судах общей юрисдикции определяется Конституцией Российской Федерации, Федеральным конституционным законом «О судебной системе Российской Федерации», настоящим Кодексом и принимаемыми в соответствии с ними другими федеральными законами, порядок гражданского судопроизводства у мирового судьи - также Федеральным законом «О мировых судьях в Российской Федерации» ${ }^{20}$. Аналогичное по своей сути положение содержится и в ст. 1.1. КоАП РФ. Следует отметить, что процессуальная форма за-

\footnotetext{
19 Уголовно-процессуальный кодекс Российской Федерации от 18.12.2001 N 174-Ф3 (ред. от 07.06.2013) // Справочно-правовая система «Консультант Плюс».

${ }^{20}$ Гражданский процессуальный кодекс Российской Федерации от 14.11.2002 N 138-Ф3 (ред. от 07.05.2013) // Справочно-правовая система «Консультант Плюс».
}

щиты прав и свобод человека и гражданина берет свое начало из конституционного права, так как в Конституции Российской Федерации закреплены основные принципы правосудия и судоустройства. О взаимосвязи процессуальных отраслей права и конституционного права свидетельствует и общность источников ${ }^{21}$. Так, источником уголовно-процессуального права, являются Уголовно-процессуальный кодекс Российской Федерации и Конституция Российской Федерации, на которой Кодекс основан.

Основанием для реализации заинтересованным лицом своих процессуальных прав является конституционное право на судебную защиту, закрепленное в ч. 1 ст. 46 Конституции РФ, является. Как отмечает С.К. Абрамян, право на судебную защиту - это субъективное право лица, реализация которого целиком зависит от его личного усмотрения. Субъективное конституционное и процессуальное право создает условия для свободы действий со знанием дела, учетом личного и публичного интересов ${ }^{22}$. В то же время данное право является государственной гарантией, благодаря которой лицо может обратиться в суд за защитой. Этому праву корреспондирует обязанность государства посредством осуществления судебной власти обеспечить эффективное восстановление нарушенных прав ${ }^{23}$.

Еще одним признаком судебной защиты прав и свобод человека и гражданина является то, что она может осуществляться как альтернатива иным средствам правовой защиты.

Примечательно, что некоторые ученые говорят о том, что судебная защита используется в тех случаях, когда другие средства правовой защиты не обеспечивают восстановление прав и свобод человека и гражданина ${ }^{24}$. Это представляется не совсем верным: судебная защита может использоваться и в тех случаях, когда добиться восстановления нарушенного права можно и другими юрисдикционными способами. Речь идет об альтернативной подведомственности дел, установленной Кодексом

\footnotetext{
${ }^{21}$ См.: Гражданский процесс: учебник / Под ред. д-ра юрид. наук проф. В.В. Яркова. М.: Волтерс Клувер. 2006. С. 8.

${ }^{22}$ См.: Абрамян С.К. Судебный механизм защиты конституционных прав граждан, страдающих психическими расстройствами // Общество и право. 2011. № 1. С. 50-52.

${ }^{23}$ См.: Витрук, Н.В. Общая теория правового положения личности. М.: Норма, 2008. C. 110-111.

${ }^{24}$ См.: Герасимова Е.B. Роль Конституционного Суда Российской Федерации в системе судебной защиты прав и свобод человека и гражданина: дис...канд.юрид.наук, СПб., 2011. С. 16.
} 


\section{Право и политика $11(166) \cdot 2013$}

Российской Федерации об административных правонарушениях (далее - КоАП РФ). Так, п. 3 ч. 1 ст. 30.1 КоАП РФ установлено, что постановление по делу об административном правонарушении, вынесенное должностным лицом, может быть обжаловано в вышестоящий орган, вышестоящему должностному лицу, либо в районный суд по месту рассмотрения дела ${ }^{25}$. Из абз. 3 ч. 4 ст. 5 Федерального закона от 17.01.1992 N 2202-1 «О прокуратуре Российской Федерации» также следует, что гражданин вправе обжаловать решение об отказе в ознакомлении с материалами проверки вышестоящему прокурору и (или) в суд.

Таким образом, судебную защиту прав и свобод человека и гражданина можно определить как активную деятельность заинтересованных субъектов (физических или юридических лиц) по реализации своих процессуальных прав в пределах, установленных законодательством, в целях защиты, восстановления либо предупреждения нарушения гарантированных государством прав и свобод.

Поскольку одна из основных задач судов в Российской Федерации - это отправление правосудия, судебную защиту прав и свобод человека и гражданина можно также определить как деятельность судебных органов по реализации своих полномочий в пределах, установленных законом. Как отмечает Л.А. Прокудина, «в последнее время при значительном расширении компетенции судов и в развитие провозглашенной и гарантированной Конституцией РФ возможности каждого на защиту его прав и свобод (ст. 46) особую актуальность приобретает вопрос - вся ли деятельность, осуществляемая судом, относится к осуществлению правосудия $)^{26}$.

По мнению Т.М. Морщаковой, «правосудие - это осуществляемая в процессуальной форме деятельность суда по реализации его исключительного полномочия по окончательному устранению правовых конфликтов путем защиты нарушенных или оспоренных прав и законных интересов» ${ }^{27}$. Думается, что приведенное определение справедливо для лю-

\footnotetext{
${ }^{25}$ Кодекс Российской Федерации об административных правонарушениях от 30.12.2001 N 195-Ф3 (ред. от 07.06.2013) // Справочно-правовая система «Консультант Плюс».

${ }^{26}$ Прокудина Л.А. Соотношение понятий «деятельность суда» и «отправление правосудия» // Право. Журнал Высшей школы экономики. 2010. № 3. C. 47. URL: pttp://ecsocman.hse.ru/hseda ta/2013/02/23/1306560554/3-2010-7.pdf

${ }^{27}$ Морщакова Т.Г. Критерии оценки судебной системы // Юридическое обозрение. 2007. № 1.
}

бых отраслей судопроизводства в той мере, в какой реализуются цели и задачи, закрепленные в законе для этой отрасли. В этой связи можно говорить о том, что суды, реализуя все свои полномочия, предусмотренные законом, осуществляют деятельность по защите прав и свобод человека и гражданина.

Представляется верной позиция Т.В. Сахновой, что «нельзя сводить правосудие к применению норм только материального права, к квалификации спорного материального правоотношения и юридическим выводам суда о действительно существующих правах и обязанностях. Правосудие - целостная категория. Вся судебная деятельность по защите, протекающая в гражданской процессуальной форме, охватывается понятием «правосудие». «Выпадение» какого-либо элемента процессуальной формы, нарушение установленных законом правил судебной защиты дезавуирует правосудие $»^{28}$.

Таким образом, система защиты прав и свобод человека и гражданина в Российской Федерации представлена тремя относительно самостоятельными, но в то же время взаимосвязанными категориями: правовая защита, государственная защита и судебная защита. Думается, что правовая защита выступает базовой категорией, внешним выражением мер, направленных на защиту прав и свобод человека и гражданина, как в порядке реализации полномочий государственными органами, так и в порядке самозащиты. Понятия «государственная защита» и «судебная защита»являются составными частями правовой защиты. При этом можно говорить о том, что данные категории являются самостоятельными и независимыми друг от друга в той мере, в какой проводится разграничение между административным и судебным порядком защиты прав и свобод человека и гражданина. Наряду с этим судебная защита является составной частью государственной защиты, так как один из ключевых субъектов охранительных правоотношений, возникающих вследствие совершения деликта, - суд - является государственным органом.

К сожалению, несмотря на то, что суды играют главную роль среди государственных механизмов обеспечения правопорядка, в настоящее время актуальным остается вопрос эффективности судебной защиты прав и свобод человека и гражданина. В российской судебной системе существуют отдельные ${ }^{28}$ Сахнова Т.В. Курс гражданского процесса: теоретические на-
чала и основные институты. М.: Волтерс Клувер. 2008. С. 21-22. 
проблемы, которые препятствуют надлежащей защите человека и гражданина: сильная загруженность судов, противоречивая государственная политика и, как следствие, нестабильность законодательства.

По причине роста количества обращений граждан за защитой своих прав и свобод, судебная система не всегда справляется с такими объемами работы. По данным Министерства юстиции РФ, за 9 месяцев 2013 года мировые судьи Челябинской области рассмотрели 313 тысяч 980 дел. В среднем на каждого судью приходится по 220 дел в месяц. Не лучше ситуация и в Вологодской области: на каждого судью там приходится по 330 дел в месяц ${ }^{29}$. У достаточно большого количества судей стандартная еженедельная нагрузка превышает 50 дел и материалов в неделю, то есть судья должен выносить решения по 10 делам или материалам в день. При восьмичасовом рабочем дне это составляет 48 минут на одно дело. ${ }^{30}$ Такая загруженность судебных органов не может не отражаться негативно на качестве правосудия, защиты прав и свобод человека и гражданина: у судей попросту не хватает времени на всестороннее и полное рассмотрение дела, надлежащее выяснение всех обстоятельств по каждому делу. Наряду с этим нарушается право гражданина на судопроизводство в разумный срок, а так же конституционная гарантия судебной защиты.

На наш взгляд, данную проблему можно устранить организационно-правовыми методами. В частности, необходимо привести отечественное процессуальное законодательство в соответствие международным стандартам. Так, в заключении №6 Консультативного Совета европейских судей Совета Европы от 24.11.2004 г. «О справедливом судебном разбирательстве в разумные сроки и роли судов в судебных процессах с учетом альтернативных способов разрешения споров» определен принцип рассмотрения дела не более чем в двух судебных заседаниях - предварительном ${ }^{31}$. При этом, доказательства и аргументы стороны должны представлять

\footnotetext{
${ }^{29}$ Cм.: URL: http://www.nr2.ru/chel/466571.htm1, http://www. krassever.ru/articles/society/sobitia/42994/ (дата обращения: 01.11.2013 г.).

${ }^{30}$ См.: URL.: http://pravo.ru/judicial_community/view/80592/ (дата обращения: 01.11.2013 г.).

${ }^{31}$ Постановление Президиума Совета Судей РФ от 24.03.2011 №257 «О результатах деятельности рабочей группы по выполнению поручения Президента Российской Федерации от 5 декабря 2010 г. №ПР-3520 о путях оптимизации нагрузки на судей» // Справочноправовая система «Консультант Плюс».
}

на предварительном судебном заседании. Для реализации этого принципа возможно расширение полномочий работников аппарата суда и ужесточение требований к их квалификации. Кроме того, важным шагом судов общей юрисдикции по оптимизации своей работы может являться использование в деятельности судов электронно-технических средств: переход на электронный документооборот, внедрение видеоконференцсвязи. Как показывает практика арбитражных судов, данная мера позволяет значительно сократить временные издержки как лиц участвующих в деле, так и самих работников суда. Такие изменения помогут более качественно проводить подготовку дела к судебному разбирательству, снизить нагрузку на судей, повысить доступность правосудия и более эффективно защищать права и свободы человека и гражданина.

Большой интерес вызывает сегодняшняя государственная политика, направленная на реформирование судебной системы. Так, по инициативе Президента Российской Федерации запущен процесс создания объединенного Верховного Суда Российской Федерации. Реализация данной инициативы не возможна без внесения поправок в Конституцию РФ: соответствующий законопроект уже внесен в Государственную Думу ${ }^{32}$. Фактически, в данном документе идет речь об упразднении Высшего Арбитражного Суда РФ и расширении полномочий Верховного Суда РФ. На счет целесообразности данной реформы есть определенные сомнения: за последние двадцать лет в России сложилась достаточно устойчивая система защиты прав и свобод человека, у граждан расширилось правосознание, появилось понимание того, что социальные конфликты должны разрешаться в судах. Кардинальная перестройка судебной системы без видимых причин может повлечь снижение эффективности ее функционирования.

Представляется, что недостаточная проработанность проекта может породить определенные проблемы в практической деятельности. Например, остается открытым вопрос организационно-технического обеспечения работы судов, которое в арбитражных судах находится на более высоком уровне, нежели в судах общей юрисдикции. Может быть затронуто право предпринимателей на рассмотрение дел в порядке надзорного производства

\footnotetext{
${ }^{32}$ Cм.: URL.: http://www.rg.ru/2013/10/10/dvoe.html (дата обращения 01.11.2013 г.).
} 
DOI: $10.7256 / 1811-9018.2013 .11 .10147$

При цитировании этой статьи сноска на dоі обязательна

\section{Право и политика $11(166) \cdot 2013$}

специализированным коллегиальным составом суда, вопрос ведения аудиопротоколов судебного заседания, возможность отслеживания судьбы дела через Интернет. Думается, что современная судебная защита должна иметь под собой достаточную материально-техническую базу. Однако ее оперативное внедрение в систему судов общей юрисдикции на данном этапе развития сопряжено с большими финансовыми затратами.

Следует подытожить, что значение института судебной защиты прав и свобод человека и гражданина для развития Российской Федерации как современного демократического и правового государства очень велико. К сожалению, в настоящее время в нашей стране не сложилось такого правосудия, которое бы в полной мере гарантировало и обеспечивало права и свободы человека и гражданина. Это выражается в различных аспектах: недостаточно эффективное администрирование судебной системы, недостаточная стабильность государственной политики в данной сфере, частые изменения законодательства, которые влекут неоднозначные правовые последствия (например, временная декриминализация отдельных уголовно-правовых норм). Все это влечет проявления нестабильности в обществе и государстве, снижение доверия граждан к судебной системе в частности и к государственной власти в целом. Ввиду неопределенности дальнейшего положения судебной системы и трудности прогнозирования направления ее развития, представляются неоднозначными предложения, направленные на объединение судов. Думается, что данный проект нуждается в детальной проработке в части обоснования необходимости его реализации, постановки конкретных целей и задач, совместимых с основной функцией судебной защиты - обеспечением законности и правопорядка в обществе.

Несмотря на наличие отдельных пробелов правового регулирования и недостаточно ясную государственную политику, судебная защита остается важнейшим инструментом поддержания общественного порядка, защиты основ конституционного строя и занимает центральное место в механизме защиты прав и свобод человека и гражданина. Хочется надеяться на то, что проводимые в стране судебные реформы будут являться предпосылкой повышения роли судебных органов в обеспечении правовой защищенности граждан и функционирования общества и государства в соответствии Конституцией РФ и нормами международного права.

\section{Библиография:}

1. Абрамян С.К. Судебный механизм защиты конституционных прав граждан, страдающих психическими расстройствами // Общество и право. 2011. № 1.

2. Алексеев С.С. Общая теория права. М., 1981. Т. 1.

3. Баглай М.В. Конституционное право Российской Федерации. М.: НОРМА, 2007.

4. Витрук, Н.В. Общая теория правового положения личности. М.: Норма, 2008.

5. Власенко Н.А. Теория государства и права: Учебное пособие. 2-е изд., перераб., доп. и испр. М.: Издательство «Проспект», 2011.

6. Малеин Н.С. Охрана прав личности советским законодательством. М., 1985.

7. Монтескье Ш. Избранные произведения. М.: Госполит-издат, 1955.

8. Морщакова Т.Г. Критерии оценки судебной системы // Юридическое обозрение. 2007. № 1.

9. Прокудина Л.А. Соотношение понятий «деятельность суда» и «отправление правосудия» // Право. Журнал Высшей школы экономики. 2010. № 3.

10. Сахнова Т.В. Курс гражданского процесса: теоретические начала и основные институты. М.: Волтерс Клувер. 2008.

11. Смирнов А.П. Соотношение понятий «охрана прав» и «защита прав» // Вестник Томского государственного университета. 2010. № 331 .

12. Столярова Ю. О. Судебная защита прав граждан как комплексный политико-правовой институт // Известия Российского государственного педагогического университета им. А.И. Герцена. 2008. № 69.

13. Халий И.А. Институты гражданского общества в современной России. К методологии изучения // Россия реформирующаяся. Ежегодник / Отв. Ред. М.К. Горшков. - Вып.6. - М.: Институт социологии PAH, 2007.

\section{References (transliteration):}

1. Abramyan S.K. Sudebnyi mekhanizm zashchity konstitutsionnykh prav grazhdan, stradayushchikh psikhicheskimi rasstroistvami // Obshchestvo i pravo. 2011. № 1 .

2. Alekseev S.S. Obshchaya teoriya prava. M., 1981. T. 1.

3. Baglai M.V. Konstitutsionnoe pravo Rossiiskoi Federatsii. M.: NORMA, 2007.

4. Vitruk, N.V. Obshchaya teoriya pravovogo polozheniya lichnosti. M.: Norma, 2008. 
5. VlasenkoN.A. Teoriya gosudarstvaiprava:Uchebnoeposobie. 2-e izd., pererab., dop. i ispr. M.: Izdatel'stvo «Prospekt», 2011.

6. Malein N.S. Okhrana prav lichnosti sovetskim zakonodatel'stvom. M., 1985.

7. Montesk'e Sh. Izbrannye proizvedeniya. M.: Gospolitizdat, 1955.

8. Morshchakova T.G. Kriterii otsenki sudebnoi sistemy // Yuridicheskoe obozrenie. 2007. № 1.

9. Prokudina L.A. Sootnoshenie ponyatii «deyatel'nost' suda» i «otpravlenie pravosudiya» // Pravo. Zhurnal Vysshei shkoly ekonomiki. 2010. № 3.

10. Sakhnova T.V. Kurs grazhdanskogo protsessa: teoreticheskie nachala i osnovnye instituty. M.: Volters Kluver. 2008.
11. Smirnov A.P. Sootnoshenie ponyatii «okhrana prav» i «zashchita prav»// Vestnik Tomskogo gosudarstvennogo universiteta. 2010. № 331.

12. Stolyarova Yu. O. Sudebnaya zashchita prav grazhdan kak kompleksnyi politiko-pravovoi institut // Izvestiya Rossiiskogo gosudarstvennogo pedagogicheskogo universiteta im. A.I. Gertsena. 2008. № 69.

13. Khalii I.A. Instituty grazhdanskogo obshchestva v sovremennoi Rossii. K metodologii izucheniya // Rossiya reformiruyushchayasya. Ezhegodnik / Otv. Red. M.K. Gorshkov.-Vyp.6.-M.: Institut sotsiologii RAN, 2007. 